\title{
ІННОВАЦІЙНИЙ MAPKETИHГ
}

УДК 004.738.5:339

JEL Classification: L81, L26, M21

Гапина П'яТницЫКА

E-mail: g.piatnytska@knute.edu.ua ORCID: 0000-0003-3463-133X

ОАеГ ГРИГОРЕНКО

E-mail: o.m.hryhorenko@knute.edu.ua ORCID: 0000-0002-2847-0149

Марина TAPACЮK

E-mail: marynkatarasiuk@gmail.com ORCID: 0000-0002-3336-6370
DOI: https://doi.org/10.31617/tr.knute.2021(37)04

д. е. н., професор,

професор кафедри менеджменту

Київського національного

торговельно-економічного університету

вум. Кіото, 19, м. Київ, 02156, Україна

к. т. н., доцент, доцент кафедри інженерно-технічних дисциплін

Київського національного

торговельно-економічного університету

вум. Кіото, 19, м. Київ, 02156, Україна

фінансовий консультант АТ "ПУМБ",

бакалавр менеджменту організацій

Київського національного

торговельно-економічного університету

вум. Кіото, 19, м. Київ, 02156, Україна

\section{ВЕНДИНГОВА ТОРГІВАЯ: ТИПІЗАЦІЯ, ПЕРЕВАГИ ТА РИЗИКИ}

Визначено переваги та недоліки/ризики вендингової торгівлі, що впливають на результати управління иією діяльністю. Проведено типізацію вендингу за предметами продажів. Запропоновано крім десяти основних типів вендингу додатково виділяти малопотирений (або одиничний) та вендинг задоволення специфічних потреб. Наведено приклади та характеристики торговельних автоматів, визначено переваги від їхньої діяльності. Виконано аналіз зміни настроїв операторів вендингової торгівлі навесні та восени 2020 р. Проведено оцінювання можливостей розвитку медичного вендингу в Украӥні.

Ключові слова: вендингова торгівля, торговельні автомати, переваги, ризики, типізація, управління діяльністю, підприємства торгівлі, стратегія, розвиток.

Постановка проблеми. Сучасний бізнес (зокрема й той, що здійснюється у сфері торгівлі) в останні два роки розвивається в умовах високого рівня невизначеності, незалежно від країни його заснування та ведення. Це прямо пов'язано 3 новими викликами, що постали перед підприємцями внаслідок глобального поширення COVID-кризи. Водночас цифровізація бізнес-процесів, активізація інноваційної діяльності підприємств, розробка та впровадження різного роду інновацій

(C) Галина П’ятницька, Олег Григоренко, Марина Тарасюк, 2021 
часто обумовлюють зміни у розвитку підприємств та галузей, сприяють підвищенню рівня якості бізнес-процесів, пов'язаних з організацією та реалізацією того чи іншого виду економічної діяльності. Проте не кожний суб'єкт підприємницької діяльності (тим більше малий за розміром і в такому, поки специфічному для України, виді бізнесу, як вендинг) здатний швидко й адекватно оцінити нові тренди розвитку в умовах COVID-кризи та забезпечити високий рівень якості логістичних процесів під час прийняття управлінських рішень у ринковому сегменті надання послуг через торговельні автомати (тобто під час здійснення діяльності й управління нею в межах секції $G$ та класу 47.99 "Інші види роздрібної торгівлі поза магазинами" за КВЕД).

Аналіз останніх досліджень і публікацій. Різні аспекти розвитку торгівлі (внутрішньої та зовнішньої, традиційної й електронної, зокрема в період розгортання COVID-кризи), результати діяльності підприємств торгівлі досліджувалися у працях як закордонних, так і українських науковців, а саме: E. Pantanoa, G. Pizzib, D. Scarpib, Ch. Dennisc [1], S. Niemeir, A. Zocchi, M. Catena [2], А. Мазаракі [3], В. Жуковської [4; 5], Л. Шимановської-Діанич, Н. Педченко [6], Н. Ільченко, І. Гарбарука [7], М. Барни [8] та ін. Були вони предметом і деяких наших попередніх досліджень [9; 10 та ін.], висновки та ідеї з яких будуть використані у цій роботі для забезпечення більш чіткого визначення переваг і ризиків від активного розвитку вендингової торгівлі.

Питанням розвитку вендингу й управління мережами торговельних автоматів на ринку послуг роздрібної торгівлі приділяли увагу вчені, як-от: R. Cardaci, S. Burgassi, D. Golinelli, N. Nante [11], які розглянули організацію та принципи розвитку багаторівневих вендингових кіберфізичних систем; Ю. Білявська та Н. Микитенко [12], що провели дослідження світового досвіду застосування вендингових автоматів і зробили загальний огляд асортименту вендингової продукції у світі, та ін. Водночас аналіз названих вище праць і практика ведення вендингової торгівлі в Україні свідчать про недостатню увагу до неї у контексті ідентифікації трендів розвитку в умовах COVIDкризи. Глибоко не вивченою залишається і проблема визначення переваг, недоліків та ризиків, які варто враховувати торговельним менеджерам, починаючи від прийняття рішення щодо стартапу і закінчуючи ймовірністю рішення про вихід з ринку надання послуг у сегменті вендингової торгівлі.

Метою дослідження є визначення основних переваг і ризиків / недоліків вендингової торгівлі в умовах її подальшого розвитку як під час COVID-кризи, так і після неї.

Для досягнення мети поставлено завдання провести типізацію вендингу залежно від предмету(ів) продажу(ів); зробити опитування менеджерів підприємств, що займаються вендинговою торгівлею, з метою визначення їхньої експертної думки щодо переваг і недоліків в управлінні вендинговим бізнесом; провести порівняльний аналіз 
думок операторів вендингової торгівлі та постачальників щодо зміни тенденцій на ринку вендинг-торгівлі навесні та восени 2020 р. у період прояву наслідків COVID-кризи.

Матеріали та методи. Для досягнення поставленої мети використано методи порівняльного аналізу, польових досліджень, анкетного опитування, аналітичної обробки даних, ідентифікації переваг і ризиків. Інформаційною базою $є$ власні дослідження авторів, дані офіційної звітності Європейської асоціації вендингу (EVA), публікації у наукових виданнях та інтернет-ресурси 3 даними про розвиток вендингу в Україні та інших країнах світу.

Результати дослідження. В умовах орієнтації на прогресивні зміни, що сприятимуть економічному зростанню та мінімізуватимуть втрати від ринкових загроз, підприємці постійно шукають інноваційні шляхи розв'язання своїх проблем в управлінні бізнесом. Міжнародний практичний досвід має реальні підтвердження фактів того, що завдяки сучасним розробкам унікального устаткування можна не тільки розв'язати проблему заощадження часових, просторових, енергетичних та інших ресурсів, зменшення витрат на оплату праці персоналу, але й отримати додатковий прибуток завдяки збільшенню каналів збуту товарів/послуг, кращому налагодженню логістики бізнес-процесів, впровадженню інноваційних технологій (наприклад технології телеметрії) тощо.

Вендингові автомати є одним із видів зазначеного вище устаткування. Саме тому торгівлю через автомати, за результатами досліджень А. Мазаракі та ін. [13], визнано високотехнологічним, рентабельним і високоприбутковим бізнесом у всьому світі. Причому підприємці, які здійснюють вендингову торгівлю, та компанії, що розвивають їі у складі свого диверсифікованого корпоративного портфеля, як правило, у стратегічній перспективі одночасно досягають двох цілей, а саме: по-перше, максимізують дохід/прибутковість своєї діяльності, підвищуючи ефективність і результативність управління нею; по-друге, мінімізують витрати (або сукупність різновидів витрат - фінансових, трудових тощо).

Польові дослідження, що проводились авторами цієї статті протягом 2018-2021 рр. як в Україні, так і поза іiі межами у країнах ЄC, а також аналіз публікацій про розвиток вендингового бізнесу в інших країнах світу [11-16 та ін.] уможливили дійти висновку, що залежно від предмету(ів) продажів існує не один тип вендингу. Сьогодні необхідно окремо вивчати і розрізняти основні типи вендингу за предметами продажів, як-от:

продуктовий, який можна поділити на декілька різновидів: штучного продажу упакованої продукції харчової промисловості; приготування гарячих/холодних, зокрема алкогольних напоїв тощо; продажу приготовленої кулінарної й кондитерської продукції та ін. При цьому продаж харчових продуктів потребує особливої уваги у питаннях створення умов для належного зберігання і дотримання його часових термінів. Крім того, деякі продукти, що дорого коштують (наприклад чорну ікру), доречно віднести до лакшері-вендингу; 
штучний (непродуктовий), що, своєю чергою, доцільно поділяти на цілу низку різновидів залежно від товарів продажу (якими, зокрема, можуть бути парасольки, навушники, краватки, шкарпетки, серветки, капці, одяг тощо);

послуг (у сегменті торговельного самообслуговування), наприклад, крісла для автоматичного масажу, що часто встановлюються у торговельних центрах, автомати для чищення взуття, фотоавтомати, сліпбокси (від англ. SleepBox - коробка для сну) - автомати, всередині яких $є$ ліжко, дзеркало, столик для ноутбука, телевізор і декілька зарядок, тобто автомати з продажу специфічних готельних послуг, завдяки яким можна відпочити, причепуритися, отримати закритий простір для роботи з ноутбуком тощо, та багато інших видів автоматів, що надають різноманітні послуги;

гральний, або івентивний (тобто подієвий, від англ. event - подія), який також може бути поділений на цілу низку різновидів 3 виділенням двох основних підгруп: орієнтовані на розважальні заклади або організацію розважальних заходів (наприклад караоке, танцювальні, гральні майданчики і т. п.) та орієнтовані на продаж іграшок. Доцільно наголосити, що до вендингових автоматів, які застосовують для продажу послуг з організації розваг або товарів для гри, не варто відносити так звані слот-машини (від англ. slot - отвір для опускання монет), що застосовуються у казино і подібних закладах. Останнє можна пояснити не тільки законодавчими нормами, що $є$ в різних країнах світу, але й тим, що слот-машини не гарантують реального продажу товару або послуги, а тому не можуть розглядатися як торговельне обладнання підприємств торгівлі;

медичний (або орієнтований на захист здоров'я), що спрямований на організацію дистанційного надання деяких медичних послуг та/або продаж товарів для захисту здоров'я;

лакшері (або дорогих товарів), коли через автомат продаються дорогі автомобілі, золоті злитки, чорна ікра й інші подібні товари;

квітково-сувенірний (або подарунковий), що можна поділити на види залежно від того, що пропонується як подарунок;

екологічний (або вторинної переробки), що орієнтований на вирішення цільових установок так званої циркулярної економіки;

поліграфічний, який можна поділити на різновиди залежно від продукції на: книжковий (зокрема з поверненням книжки як різновиду бібліотечних послуг); поштовий (з продажу конвертів та/або листівок), 3 друку плакатів (наприклад, для зустрічі в аеропорту) тощо;

змішаний, коли в торговельному автоматі передбачається продаж не однорідної, а диференційованої за призначенням споживання продукції.

Звичайно, крім перелічених типів, додатково можна виділити тип малопоширеного, або одиничного вендингу, до якого віднести автоматизовану торгівлю чимось таким, що так само мало продається або взагалі не продається в інших місцях. Окремо варто вирізняти і вендинг для задоволення специцфічних потреб або попиту. До такого, 
наприклад, має сенс віднести вендинг з продажу ношеної білизни, попит на який в Японії вже багато років задовольняється за допомогою спеціальних торговельних автоматів.

Надалі 3 метою визначення й оцінювання сильних та слабких сторін в управлінні вендинговим бізнесом можна рекомендувати більш детально зупинятися на дослідженні певного різновиду вендингу в межах того чи іншого типу. Це дасть змогу більш зважено та науково обгрунтовано підходити до прийняття управлінських рішень щодо розвитку мереж певних різновидів автоматів та збільшення обсягів вендингової торгівлі.

У таблиці зведено, схарактеризовано та визначено основні переваги торгових (вендингових) автоматів, що можуть бути віднесені до одного $з$ перелічених вище типів вендингу.

\begin{tabular}{|c|c|c|}
\hline $\begin{array}{l}\text { Країна, місце розмі- } \\
\text { щення вендингового } \\
\text { автомата }\end{array}$ & Характеристика & $\begin{array}{l}\text { Переваги від типу/різновиду } \\
\text { вендингової діяльності }\end{array}$ \\
\hline \multicolumn{3}{|c|}{ Медичний (або орієнтований на захист здоров'я) вендинг } \\
\hline $\begin{array}{l}\text { Латвія, Клінічна } \\
\text { університетська } \\
\text { лікарня Паулса } \\
\text { Страдінса у м. Рига } \\
\end{array}$ & \multirow{2}{*}{$\begin{array}{l}\text { Автомат із ПЦР-тестами - } \\
\text { видає та зберігає зразки } \\
\text { тестів, передбачає обробку } \\
\text { тестів протягом } 24 \text { годин } \\
\text { в клініці }\end{array}$} & $\begin{array}{l}\text { Позбавляє потреби наявності від двох до п’яти } \\
\text { медичних працівників для проведення тестів, } \\
\text { а також усуває будь-який ризик зараження }\end{array}$ \\
\hline $\begin{array}{l}\text { Японія, територія } \\
\text { буддійського храму } \\
\text { Джомьоін, м. Токіо } \\
\text { (автомат належить } \\
\text { ЛОР-клініці Takenoko) }\end{array}$ & & $\begin{array}{l}\text { Про результати позитивного тесту надходить негайне } \\
\text { електронне повідомлення не тільки клієнту, який } \\
\text { тестувався, а й місцевому відділенню охорони } \\
\text { здоров’я, щоб призначити лікування та процедуру } \\
\text { карантину; працеощадність; економія часу } \\
\text { обслуговування }\end{array}$ \\
\hline $\begin{array}{l}C Ш А, \text { Міжнародний } \\
\text { аеропорт Окленда, } \\
\text { Каліфорнія }\end{array}$ & $\begin{array}{l}\text { Автомат з продажу експрес- } \\
\text { тестів та ПЦР для само- } \\
\text { стійного проведення тесту- } \\
\text { вання в домашніх умовах } \\
\end{array}$ & $\begin{array}{l}\text { Швидке тестування авіапасажирів: за допомогою } \\
\text { експрес-тесту результат можна отримати за } 15 \text { хвилин }\end{array}$ \\
\hline $\begin{array}{l}\text { Різні краӥни світу, } \\
\text { авто-, залізничні } \\
\text { вокзали, аеропорти }\end{array}$ & $\begin{array}{l}\text { Автомати з продажу } \\
\text { медичних масок } \\
\text { й антисептиків }\end{array}$ & $\begin{array}{l}\text { Доступ до товарів захисту в місцях великого } \\
\text { скупчення; допомога у реалізації міжнародних } \\
\text { заходів захисту здоров’я }\end{array}$ \\
\hline \multicolumn{3}{|c|}{ Продуктовий вендинг } \\
\hline $\begin{array}{l}\text { Україна, } \\
\text { Київський національ- } \\
\text { ний торговельно- } \\
\text { економічний } \\
\text { університет, м. Київ }\end{array}$ & $\begin{array}{l}\text { Автомати з харчовими } \\
\text { продуктами (бутельовані } \\
\text { напої, упаковані чипси, } \\
\text { шоколад тощо). } \\
\text { Автомати, що готують } \\
\text { та продають гарячі напої } \\
\text { (каву, чай) }\end{array}$ & $\begin{array}{l}\text { Підвищує якість задоволення потреби викладачів } \\
\text { і студентів у додатковому харчуванні; різновид } \\
\text { практично безконтактного каналу продажу харчових } \\
\text { продуктів та/або напоїв, що особливо цінно в умовах } \\
\text { пандемії COVID-19 і обмеження режиму роботи } \\
\text { закладів ресторанного господарства; уможливлює } \\
\text { надавати послуги для задоволення фізіологічної } \\
\text { потреби у харчуванні цілодобово і без вихідних; } \\
\text { може здійснюватися не тільки у закладах освіти, } \\
\text { що дає можливість переміщення у просторі }\end{array}$ \\
\hline $\begin{array}{l}\text { Україна, } \\
\text { Європейський ліцей, } \\
\text { м. Одеса }\end{array}$ & $\begin{array}{l}\text { Автомати самообслуго- } \\
\text { вування } 3 \text { продажу при- } \\
\text { готовлених гарячих } \\
\text { і холодних страв }\end{array}$ & $\begin{array}{l}\text { Уможливлює реалізувати альтернативний підхід } \\
\text { організації харчування за місцем навчання; } \\
\text { смс-повідомлення батьків про вибір дитини у разі } \\
\text { карткового розрахунку, що дає змогу здійснювати } \\
\text { контроль за тим, наскільки якісним є харчування; } \\
\text { уможливлює оптимізувати витрати часу на } \\
\text { обслуговування та мінімізувати кількість } \\
\text { контактів }\end{array}$ \\
\hline
\end{tabular}




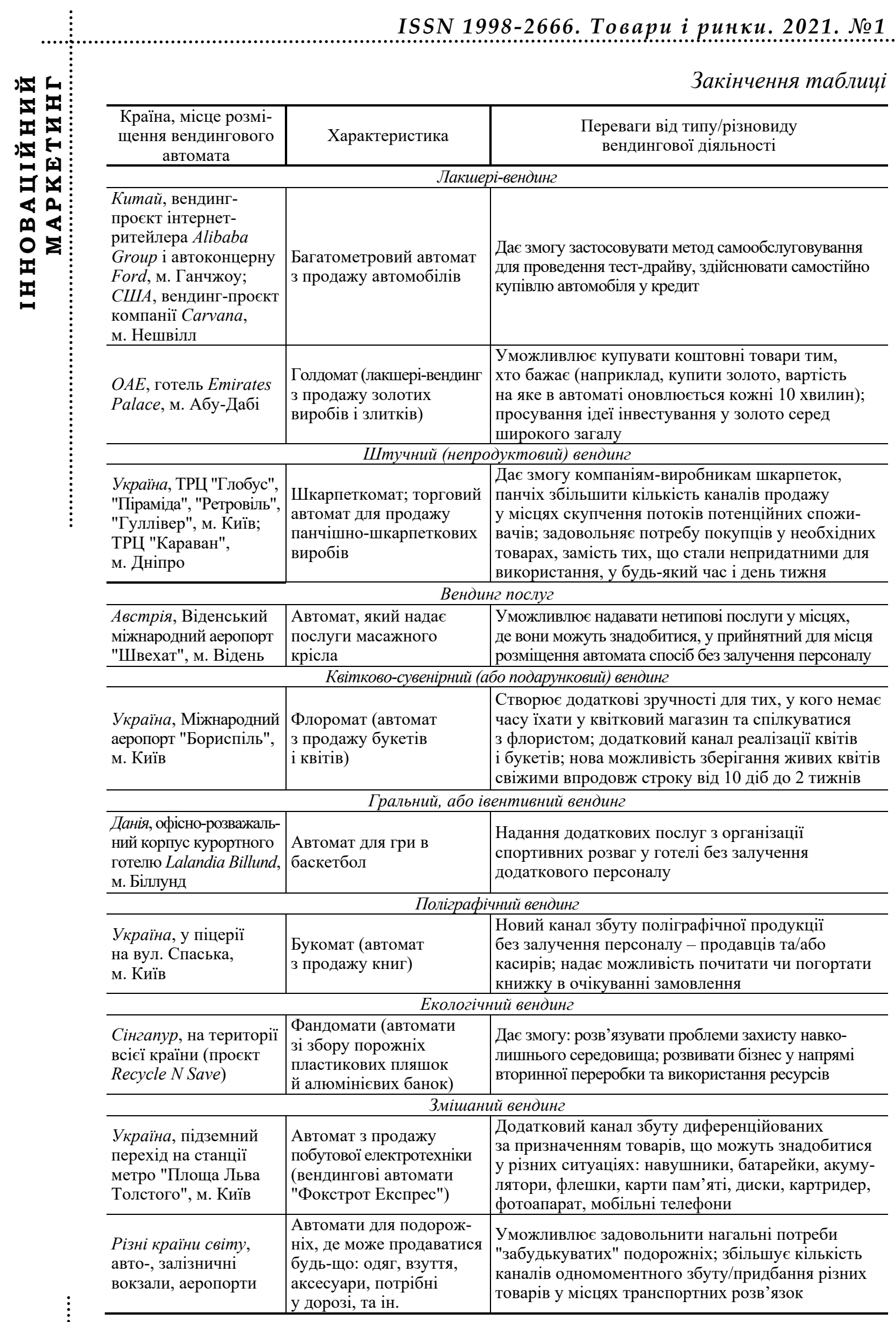

* Джерело: розроблено авторами за результатами власних польових досліджень й аналізу різних інформаційних джерел [16-21]. 
Сьогодні, як свідчать наведені дані, вендингові автомати продають не тільки гарячі та холодні напої, цигарки, напівфабрикати, фрукти, овочі, періодичну пресу, але й золото, автомобілі та багато іншого. Простота моделі вендингової торгівлі робить ï особливо привабливою як для підприємців-початківців, так і для компаній, що приймають рішення диверсифікувати свою діяльність на ринку в умовах, коли "...у роботі з клієнтами отримали широке поширення безконтактні технології, а також комплексне ... обслуговування онлайн "на ходу" та в магазинах" [5, с. 117].

Привабливість вендингового бізнесу пояснюється його успішністю і рентабельністю. Це один із небагатьох видів економічної діяльності, що, за оцінками експертів, дає максимум прибутку за мінімум часу: вкладений капітал протягом декількох місяців обертається сотнями відсотків. Сучасні вендинг-машини, як правило, являють собою високотехнологічне обладнання 3 необмеженими опціями і можливостями, що характеризуються високою мобільністю. До того ж ринок вендинг-автоматів невпинно зростає, змінюється, поповнюється більш досконалими й економічними моделями вендингових машин [14].

Беззаперечною перевагою вендингової торгівлі $\epsilon$ те, що для обслуговування торгових автоматів зазвичай необхідний лише один працівник, але водночас це $\epsilon$ i недоліком. Торгові автомати потребують щомісячного технічного огляду, і $є$ ймовірність їх поломок, що вимагає певної кваліфікації від персоналу для їх усунення. Проведене авторами у 2021 р. опитування 12 менеджерів підприємств, що утримують у своєму диверсифікованому корпоративному портфелі стратегічні одиниці вендингового бізнесу, які у межах цього дослідження залучалися як експерти, дало змогу визначити основні переваги і недоліки, що відповідним чином впливають на результати управління вендинговою торгівлею на практиці.

Переваги у вендинговій торгівлі, крім наведених на рисунку, прямо залежать від якості обладнання - торгових автоматів. 3 розвитком цифровізації бізнесу зростає попит на автомати, що дають змогу не тільки застосовувати різні формати оплати, але й завантажувати та керувати рекламою в автоматі, збирати й обробляти статистичні дані тощо. До переваг автоматів у вендинговій торгівлі відносять їхні можливості дистанційно у режимі реального часу проводити моніторинг залишків товарів, продажів, помилок, змінювати ціну, видавати товар, контролювати й управляти температурою всередині автомата, завантажувати контент, порядок показу та таймінг реклами тощо. Зауважимо, що в Україні сьогодні єдиним виробником вендингового обладнання є компанія "АВАНГАРД". Набагато більше таких виробників у Японії й США, де вендингова торгівля вже добре розвинена й охоплює збут та просування самих різних категорій товарів і послуг. Про це свідчать такі факти [22]: ще на початку 2017 р. в Японії встановлено 5.6 млн автоматів (тобто один у розрахунку на 23 мешканці), у США - 15.4 млн автоматів (тобто один у розрахунку на 20 мешканців). У цілому в Свропі на початок 2017 р. налічувалося 
понад чотири мільйони торгових автоматів (один у розрахунку на 190 мешканців). Причому серед країн Східної Свропи протягом 20122016 рр. найбільше зростання кількості торговельних автоматів відбувалося у Польщі $-7.8 \%$ за середнього зростання світового вендингу у 2.5-3.0\%. В Україні на той період працювало близько 10 тис. вендингових автоматів (переважно в містах-мільйонниках), тобто один автомат припадав на 4.0-4.5 тис. мешканців країни. На початок 2020 р., за даними, презентованими у VendingSolution компанії "АВАНГАРД" [23], цей показник покращився, і в Україні на один вендинговий автомат тепер припадає 1615 мешканців (для порівняння, в Японії - 16 мешканців на один автомат, або у понад 1.4 раза менше мешканців у розрахунку на один торговельний автомат, ніж було на початку 2017 р.).

\begin{tabular}{|c|c|}
\hline \multicolumn{2}{|c|}{ ВЕНДИНГОВА ТОРГІВЛЯ } \\
\hline \multicolumn{2}{|l|}{ Переваги } \\
\hline 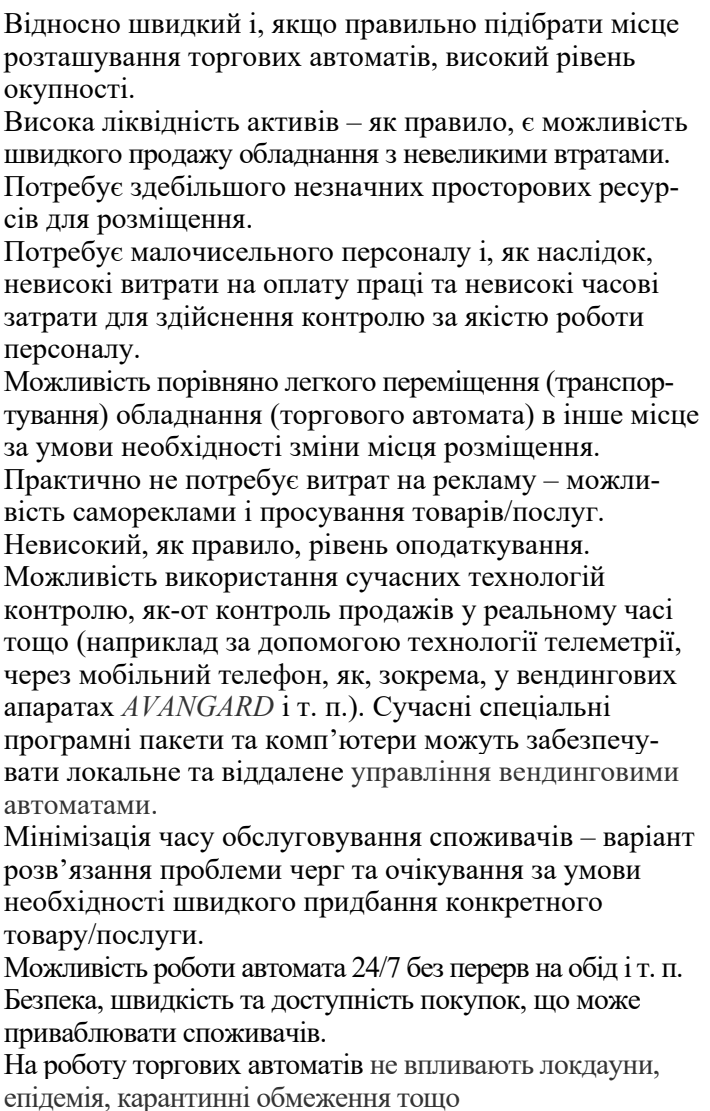 & $\begin{array}{l}\text { Необхідність перманентного технічного обслу- } \\
\text { говування, яке у разі частих технічних поломок } \\
\text { може виявитися надмірно витратним. } \\
\text { Залежність від електромережі та витрат } \\
\text { на електроенергію. } \\
\text { Велика пряма залежність прибутку від місця } \\
\text { розташування та предмету(ів) продажів - } \\
\text { ймовірні високі ризики прорахунків внаслідок } \\
\text { невдалого місця розміщення та/або вибору пред- } \\
\text { мету(ів) для продажу. } \\
\text { Ризики навмисного фізичного виведення торго- } \\
\text { вого автомата з ладу (непередбачуваність } \\
\text { поведінки вандалів). } \\
\text { Ризики ймовірної різкої зміни законодавства } \\
\text { у сфері вендингової торгівлі. } \\
\text { Ризики ймовірної невисокої лояльності з боку } \\
\text { покупців, якщо торговий автомат або не } \\
\text { задовольняє їхніх очікувань, або покупці мали } \\
\text { негативний досвід користування автоматами. } \\
\text { Ризик обмежень для споживачів щодо форм } \\
\text { оплати (наприклад, якщо платити потрібно тільки } \\
\text { готівкою з використанням купюр лише певного } \\
\text { номіналу), що може обмежувати доступність. } \\
\text { Імовірність високої інтенсивності конкуренції з } \\
\text { традиційними об’єктами торгівлі, що продають } \\
\text { аналогічні товари/послуги. } \\
\text { Значні стартап-витрати (особливо якщо купувати } \\
\text { не один, і не два автомати). Зауважимо, що купу- } \\
\text { вати один автомат, як правило, економічно } \\
\text { невигідно. } \\
\text { Обмежений за широтою та глибиною товарний } \\
\text { асортимент. } \\
\text { Ризик перебоїв у постачанні товарів (несвоєчас- } \\
\text { ніть поповнення запасів) }\end{array}$ \\
\hline
\end{tabular}

Основні переваги та недоліки/ризики вендингової торгівлі як чинники впливу на результати управління нею*

* Джерело: розроблено авторами. 
Отже, в Україні забезпеченість населення вендинговими автоматами майже у 101 раз гірша, ніж в Японії. Безумовно, цьому може бути декілька причин: починаючи від популярності вендингової торгівлі в Японії, головно у зв'язку з орієнтацією бізнесу на пошук просторовоощадних рішень та створення широких можливостей для збуту через самообслуговування 24/7, та закінчуючи тим, що в Україні більшість мешканців ще ставиться з пересторогою до покупок за допомогою вендинг-автоматів чогось більш складного, ніж гарячі та холодні напої тощо, а також далеко не все населення (особливо старшої вікової категорії) має досвід користування новітніми технологіями, зокрема автоматами останніх років випуску. Хоча торгові автомати газованої води були розміщені просто на вулицях в усіх містах України ще в минулому сторіччі. Сьогодні їм на зміну прийшли більш технічно складні автомати, що можуть готувати напої з опцією вибору складу наповнення самим споживачем і навіть у тій пропорції, що йому необхідна (наприклад, якщо йдеться про додавання кількості цукру до чаю або кави). Водночас, як свідчать дані (див. таблищю), у країні поступово розвиваються й інші (непродуктові) напрями вендингу.

Аналізуючи переваги та ризики вендингової торгівлі "...у період турбулентності ринкового середовища, коли підприємства торгівлі стикаються 3 новими викликами" [10, с. 6], потрібно обов'язково розглянути зміну настроїв торгових операторів, що нею займаються у різних країнах світу. Дані, що наведені вище (див. рисунок), та звітів EVA навесні та восени 2020 р. свідчать, що вендингова торгівля, за результатами опитування торгових операторів і постачальників вендингового обладнання, платіжних систем й інгредієнтів, у 13 країнах Європи зазнала певних змін у період поширення наслідків COVID, і ці зміни з часом мають стримано оптимістичний характер розвитку. Про це, на додаток до вже зазначених, свідчать такі факти [15; 24]:

- якщо у квітні 2020 р. 58 \% операторів ведингової торгівлі спостерігали зниження обороту на 61-99\%, як порівняти з аналогічним періодом 2019 р., то у вересні тільки $48 \%$ операторів мали втрати в товарообігу в межах 21-40\%;

- основною причиною втрат обороту вендингової торгівлі називається те, що багато працівників переведені у дистанційний режим роботи і почали працювати вдома;

- навесні 2020 р. 70 \% вендинг-операторів вважали, що подальша криза призведе до змін у поведінці споживачів послуг торгових автоматів;

- $60 \%$ операторів зауважили високий попит на безготівковий розрахунок;

- протягом осіннього періоду 2020 р. більше операторів (43\%) планували інвестиції на основі результатів продажів проти весняного періоду (33 \%), що є підставою для оптимізму;

- у квітні 2021 р. лише 14 \% постачальників очікують подібного до 2019 р. обороту. 
До ризиків, які могли стати на заваді успішному розвитку вендинг-торгівлі в період COVID-кризи, варто віднести і ймовірність порушення ланцюгів поставок. Останнє безумовно потребує пошуку нових альтернативних рішень логістичних завдань, перегляду логістичних стратегій підприємств, що займаються вендинговою торгівлею.

Водночас активізація розвитку вендингової торгівлі, на відміну від електронної комерції, розвиток якої цілком "...може призвести до зменшення каналів традиційної гуртово-роздрібної торгівлі" [9, с. 127], створює додаткові канали збуту та просування товарів/послуг як у межах діяльності традиційних підприємств торгівлі, так і поза ними. Розвинення вендингової торгівлі передусім спрямоване на розв'язання проблеми вузьких місць у традиційній торгівлі, коли споживач: не хоче очікувати у черзі на придбання якогось необхідного йому штучного товару (і підприємство торгівлі його може просто втратити); хоче придбати певний товар у той час і в тому місці, де ніхто інший таку торговельну послугу йому надати не може. Поряд 3 цим з розвитком технології телеметрії вендинг-торгівля набуває унікальних переваг для забезпечення якісного дистанційного управління автоматами, що вкрай важливо в умовах пандемії та необхідності мінімізації комунікацій типу "людина - людина".

Висновки. Основними перевагами вендингової торгівлі $\epsilon$, nо-перше, порівняно швидкий строк окупності у разі вдалого місця розміщення та вибору товарів, попит на які $\epsilon$ високим; по-друге, низька трудомісткість проти традиційної торгівлі; по-третє, можливість дистанційного управління та контролю в режимі реального часу; по-четверте, можливість надання торговельних послуг у режимі 24/7 3 дотриманням безпеки і мінімізації контактів (якщо це необхідно в умовах COVID). Основні ризики в період локдауну пов'язані з розірванням або недоліками у роботі традиційних ланцюгів поставок та зменшенням продажів через домашній карантин i, як наслідок, зі зростанням імовірності економічно невиправданих енерговитрат, витрат на щомісячне технічне обслуговування автоматів тощо.

Для України ризиковим $є$ й те, що переважна більшість населення країни не має якісно сформованого досвіду купівлі-продажу товарів/ послуг через автомати (за винятком продуктового сегмента товарної пропозиції).

В умовах пандемії деякі сегменти вендингової торгівлі мають перспективи для зростання продажів, зокрема медичний вендинг. Надалі це може бути перспективним напрямом розвитку та надання через торговельні автомати інших медичних послуг. Проте встановлення таких апаратів, на жаль, навряд чи буде економічно вигідним у сільській місцевості України, з малою кількістю мешканців (хоча й може використовуватися у сільських медлабораторіях, де бракує персоналу і частину послуг просто необхідно перевести у режим само- 
обслуговування). Досвід США, де автомати ще до початку пандемії застосовували для продажу ліків за рецептами, також, на жаль, поки виглядає як малоперспективний для України.

Надалі отримані результати дослідження можуть бути використані для розробки альтернативних стратегій розвитку як підприємств торгівлі, так і інших видів економічної діяльності, для яких вендингторгівля може стати супутньою послугою в процесі забезпечення високоякісного сервісу для споживачів їхніх товарів/послуг та створення комфортних умов праці для співробітників тощо. Більш детально на основі отриманих результатів можна вивчати й проблемні аспекти управління логістичними процесами у вендинговій торгівлі.

\section{СПИСОК ВИКОРИСТАНИХ ДХЕРЕА}

1. Pantanoa E., Pizzib G., Scarpib D., Dennisc Ch. Competing during a pandemic? Retailers' ups and downs during the COVID-19 outbreak. Journal of Business Research. 2020. Vol. 116. P. 209-213.

2. Niemeir S., Zocchi A., Catena M. Reshaping Retail: Why Technology is Transforming the Industry and how to Win in the new Consumer Driven World. Wiley, 2013. 208 p.

3. Мазаракі А. А., Лагутін В. Д., Герасименко А. Г. та ін. Внутрішня торгівля України: монографія; за заг. ред. д-ра екон. наук, проф. А. А. Мазаракі. Київ: Київ. нац. торг.-екон. ун-т, 2016. 864 с.

4. Жуковська В. М. Соціальні важелі впливу на розвиток підприємств торгівлі. Бізнес-навігатор. 2018. Вип. 1-1. С. 118-123.

5. Пятницкая Г. Т., Жуковская В. Н. Развитие внутренней торговли: современные трансформации и приоритеты социализации. Актуальні проблеми економіки. 2015. № 11 (173). С. 106-119.

6. Шимановська-Діанич Л. М., Педченко Н. С. Підходи до оцінки ефективності та результативності діяльності торговельного підприємства: сучасний погляд. Соціально-економічні проблеми сучасного періоду Украӥни. 2019. Вип. 1 (135). С. 71-77.

7. Ільченко Н. Б., Гарбарук І. М. Глобальні тренди розвитку роздрібної торгівлі. Наук. вісн. Міжнар. гум. ун-ту. 2018. Вип. 31. С. 32-38.

8. Барна М. Концепція розвитку системи внутрішньої торгівлі України в сучасних умовах трансформації. Інвестиції: практика та досвід. 2015. № 10 . С. 63-70.

9. П'ятницька Г. Т., Григоренко О. М. Електронна комерція В2С: розвиток у Східній Європі, ризики та ефект інституціонального витіснення. Менеджмент та підприємництво в Україні: етапи становлення та проблеми розвитку. Львів: Вид-во "Львівська політехніка", 2019. Т. 1. № 1. С. 122-130.

10. П'ятницька Г., Григоренко О., Шевчун М. Внутрішня торгівля України: структурно-динамічний аналіз. Міжнар. наук.-практ. журн. "Товари і ринки". 2020. № 3. C. 5-21. DOI: https://doi.org/10.31617/tr.knute.2020(35)01.

11. Cardaci R., Burgassi S., Golinelli D., Nante N., Battaglia M. A., Bezzini D. et al. Automatic Vending-Machines Contamination: A Pilot Study. Global Journal of Health Science. 2017. Vol. 9. N 2. P. 63-67. 
12. Білявська Ю. В., Микитенко Н. В. Вендинг в умовах пандемії COVID-19: зарубіжний та вітчизняний досвід. Наук. вісн. Херсон. держ ун-ту. Серія "Економічні науки". 2020. Вип. 40. С. 13-18.

13. Мазаракі А. А., Пшеслінський Д. М., Смолін І. В. Торговельне підприємство: стратегія, політика, конкурентоспроможність: монографія. Київ: Київ. нац. торг.-екон. ун-т, 2010. 384 с.

14. Горбаль Н. І., Келлер 3. Ю., Найчук-Хрущ М. Б. Вендинговий стартап на українському ринку. Наук. вісн. НЛТУ України. Серія: Економічна. 2017. Вип. 27. № 2. С. 53-57.

15. European Vending Association Reports "Marked' Improvement for Industry". 13.01.2021. URL: https://www.vendingmarketwatch.com/management/news/ 21205631/european-vending-association-reports-marked-improvement-for-industry.

16. ТОП-15 самых необычных вендинговых автоматов. URL: https:/infobus.eu/ blog/top-15-samyh-neobychnyh-vendingovyh-avtomatov.

17. Latvia to Roll Out COVID Tests Through Vending Machines. URL: https://www.planet-vending.com/latvia-to-roll-out-covid-tests-throughvending-machines.

18. Вендинг автоматы с тестами на COVID-19 установят в Международном аэропорту Окленда. URL: https:/kiosksoft.ru/news/2021/01/19/vendingavtomaty-s-testami-na-covid-19-ustanovyat-v-mezhdunarodnom-aeroportuoklenda-10502.

19. В Японии наборы с ПЦР тестами на Covid-19 продаются в вендинг автоматах. URL: https://kiosksoft.ru/news/2021/02/04/v-yaponii-nabory-s-pcr-testamina-covid-19-prodayutsya-v-vending-avtomatah-64311.

20. Сингапурская сеть фандоматов доказала свою эффективность. URL: https://kiosksoft.ru/news/2020/12/30/singapurskaya-set-fandomatov-dokazalasvoyu-effektivnost-77296.

21. В Китае открыли 20-метровый автомат по продаже автомобилей. URL: https://rau.ua/ru/news/avtomat-po-prodazhe-avtomobiley.

22. Симоненко К. Продажі без продавців: торговельні автомати все частіше замінюють людину. Офіційний сайт Асоціації ритейлерів України RAU. 17.07.2019. URL: https://rau.ua/novyni/prodazhi-torgovelni-avtomaty.

23. Ринок вендингу - один із найбільш динамічно зростаючих ринків. Vending-Solution компанії Avangard. URL: http://www.findglocal.com/UA/ Vyshneve/112175550419685/VendingSolution.

24. Market Information: Data from the official site of European Vending \& Coffee Service Association. URL: https://www.vending-europe.eu/activities/ market-information.

Стаття надійшла до редакиії 10.02.2021.

\section{fits and risks.}

Piatnytska G., Hryhorenko O., Tarasiuk M. Vending trade: typification, bene-

Background. In the last two years modern business is developing in a high level of uncertainty, regardless of the country of its establishment and doing. Not every business entity (especially small in size and in such a specific for Ukraine type of business as vending) is able to quickly and adequately assess new development trends in the COVID crisis, to properly use their advantages, given the new risks.

Analysis of recent research and publications has shown that despite the not new practice of vending trade in Ukraine, so far insufficient attention has been paid to identifying trends in vending in the COVID crisis, identifying advantages, disadvantages and 
risks that should be considered by trade managers from the decision to startup and ending with the probability of deciding to exit the market of services in the segment of vending.

The aim of the article is to determine the main advantages and risks / disadvantages of vending trade in the conditions of its further development both during the COVID crisis and after it.

Materials and methods. In the course of the research the methods of comparative analysis, field research, questionnaire survey, analytical data processing, identification of advantages and risks were used.

Research. The advantages and disadvantages / risks of vending trade that affect the results of management of this activity are identified. The main advantages of vending trade include: fast payback period with successful placement of machines; low level of labor intensity; possibility of remote control and management; operation of machines in $24 / 7$ mode. It is established that the main risks during the lockdown period are the risks associated with the breakdown or shortcomings of traditional supply chains and reduced sales due to the introduction of home quarantine and, consequently, increasing the likelihood of economically unjustified energy costs, costs of monthly maintenance, etc. Typification of vending by subjects of sales is carried out. It is proposed to distinguish ten main types of vending: product, artificial (non-product), services, gambling or event, medical, luxury, floral (flower and souvenir), environmental, printing, mixed, as well as - less common (or single) and vending to meet specific needs. Examples of the main types of vending in different countries of the world are presented. The general characteristics of vending machines are given and advantages from their activity are defined. An analysis of the change in the mood of the vending business operators based on the results of their survey in the spring and autumn of 2020, the period of the consequences of the COVID crisis, was carried out. The possibilities of medical vending development in Ukraine were evaluated.

Conclusion. It is established that for Ukraine, in addition to the general above-mentioned risks of vending trade, it is also risky that the vast majority of the country's population does not have high-quality experience of buying and selling goods / services through vending machines (excluding food segment). It is concluded that in a pandemic, some segments of vending trade (in particular, medical vending) have prospects for sales growth.

In the future, the results of the study can be used to develop alternative development strategies of trade enterprises and enterprises with other economic activities for which vending trade can become a related service in the process of providing high quality service to consumers of their goods, creating comfortable working conditions for employees, etc.

Keywords: vending trade, vending machines, advantages, risks, typification, management of activity, trade enterprises, strategy, development.

\section{REFERENCES}

1. Pantanoa, E., Pizzib, G., Scarpib, D., \& Dennisc, Ch. (2020). Competing during a pandemic? Retailers' ups and downs during the COVID-19 outbreak. Journal of Business Research. (Vol. 116), (pp. 209-213) [in English].

2. Niemeir, S., Zocchi, A., \& Catena, M. (2013). Reshaping Retail: Why Technology is Transforming the Industry and how to Win in the new Consumer Driven World. Wiley [in English].

3. Mazaraki, A. A., Lagutin, V. D., Gerasymenko, A. G. et al. (2016). Vnutrishnja torgivlja Ukrai'ny [Internal trade of Ukraine]. A. A. Mazaraki (Ed.). Kyi'v: Kyi'vs'kyj nacional'nyj torgovel'no-ekonomichnyj universytet [in Ukrainian].

4. Zhukovs'ka, V. M. (2018). Social'ni vazheli vplyvu na rozvytok pidpryjemstv torgivli [Social levers of influence on the development of trade enterprises]. Biznesnavigator - Business navigator. (Issue 1-1), (pp. 118-123) [in Ukrainian]. 
5. Pjatnyckaja, G. T., \& Zhukovskaja, V. N. (2015). Razvytye vnutrennej torgovly: sovremennыe transformacyy y pryorytetы socyalyzacyy [Development of internal trade: modern transformations and priorities of socialization]. Aktual'ni problemy ekonomiky - Actual problems of economy, 11 (173), 106-119 [in Russian].

6. Shymanovs'ka-Dianych, L. M., \& Pedchenko, N. S. (2019). Pidhody do ocinky efektyvnosti ta rezul'tatyvnosti dijal'nosti torgovel'nogo pidpryjemstva: suchasnyj pogljad [Approaches to assessing the efficiency and effectiveness of a commercial enterprise: a modern view]. Social'no-ekonomichni problemy suchasnogo periodu Ukrai'ny Socio-economic problems of the modern period of Ukraine. (Issue 1 (135), (pp. 71-77) [in Ukrainian].

7. Il'chenko, N. B., \& Garbaruk, I. M. (2018). Global'ni trendy rozvytku rozdribnoi' torgivli [Global trends in retail development]. Naukovyj visnyk Mizhnarodnogo gumanitarnogo universytetu - Scientific Bulletin of the International Humanitarian University. (Issue 31), (pp. 32-38) [in Ukrainian].

8. Barna, M. (2015). Koncepcija rozvytku systemy vnutrishn'oi' torgivli Ukrai'ny $\mathrm{v}$ suchasnyh umovah transformacii' [The concept of development of the system of internal trade of Ukraine in modern conditions of transformation]. Investycii': praktyka ta dosvid - Investments: practice and experience, 10, 63-70 [in Ukrainian].

9. P'jatnyc'ka, G., \& Grygorenko, O. M. (2019). Elektronna komercija V2S: rozvytok u Shidnij Jevropi, ryzyky ta efekt instytucional'nogo vytisnennja [B2C e-commerce: development in Eastern Europe, risks and the effect of institutional displacement]. Menedzhment ta pidpryjemnyctvo $v$ Ukrai'ni: etapy stanovlennja ta problemy rozvytku-Management and entrepreneurship in Ukraine: stages of formation and problems of development. (Vol. 1), 1, 122-130. L'viv: Vydavnyctvo "L'vivs'ka politehnika" [in Ukrainian].

10. P'jatnyc'ka, G., Grygorenko, O., \& Shevchun, M. (2020). Vnutrishnja torgivlja Ukrai'ny: strukturno-dynamichnyj analiz [Internal trade of Ukraine: structural and dynamic analysis]. Mizhnarodnyj naukovo-praktychnyj zhurnal "Tovary i rynky" - International Scientific and Practical Journal "Commodities and Markets", 3, 5-21. DOI: https://doi.org/10.31617/ tr.knute.2020(35)01 [in Ukrainian].

11. Cardaci, R., Burgassi, S., Golinelli, D., Nante, N., Battaglia, M. A., Bezzini, D. et al. (2017). Automatic Vending-Machines Contamination: A Pilot Study. Global Journal of Health Science. (Vol. 9), 2, 63-67 [in English].

12. Biljavs'ka, Ju. V., \& Mykytenko, N. V. (2020). Vendyng v umovah pandemii' COVID-19: zarubizhnyj ta vitchyznjanyj dosvid [Vending in the context of the COVID-19 pandemic: foreign and domestic experience]. Naukovyj visnyk Hersons 'kogo derzhavnogo universytetu. Serija "Ekonomichni nauky" - Scientific Bulletin of Kherson State University. Series "Economic Sciences". (Issue 40), (pp. 13-18) [in Ukrainian].

13. Mazaraki, A. A., Psheslins'kyj, D. M., \& Smolin, I. V. (2010). Torgovel'ne pidpryjemstvo: strategija, polityka, konkurentospromozhnist' [Trading company: strategy, policy, competitiveness]. Kyi'v: Kyi'vs'kyj nacional'nyj torgovel'no-ekonomichnyj universytet [in Ukrainian].

14. Gorbal', N. I., Keller, Z. Ju., \& Najchuk-Hrushh, M. B. (2017). Vendyngovyj startap na ukrai'ns'komu rynku [Vending startup on the Ukrainian market]. Naukovyj visnyk NLTU Ukrai'ny. Serija: Ekonomichna - Scientific Bulletin of UNFU of Ukraine. Series: Economic. (Issue 27), 2, 53-57 [in Ukrainian].

15. European Vending Association Reports "Marked' Improvement for Industry". Retrieved from https://www.vendingmarketwatch.com/management/news/21205631/europeanvending-association-reports-marked-improvement-for-industry [in English].

16. TOP-15 samyh neobychnyh vendingovyh avtomatov [TOP 15 of the most unusual vending machines]. Retrieved from https://infobus.eu/blog/top-15-samyh-neobychnyh-vendingovyh-avtomatov [in Russian].

17. Latvia to Roll Out COVID Tests Through Vending Machines. Retrieved from $\mathrm{https}$ ://www.planet-vending.com/latvia-to-roll-out-covid-tests-through-vending-machines [in English]. 
18. Vending avtomaty s testami na COVID-19 ustanovjat $v$ Mezhdunarodnom ajeroportu Oklenda [Vending machines with COVID-19 tests to be installed at Auckland International Airport]. Retrieved from https://kiosksoft.ru/news/2021/01/19/vending-avtomatys-testami-na-covid-19-ustanovyat-v-mezhdunarodnom-aeroportu-oklenda-10502 [in Russian].

19. V Japonii nabory s PCR testami na Covid-19 prodajutsja $v$ vending avtomatah [In Japan, PCR test kits for Covid-19 are sold in vending machines]. Retrieved from https://kiosksoft.ru/news/2021/02/04/v-yaponii-nabory-s-pcr-testami-na-covid-19prodayutsya-v-vending-avtomatah-64311 [in Russian].

20. Singapurskaja set' fandomatov dokazala svoju jeffektivnost' [Singapore fandom network has proven to be effective]. Retrieved from https://kiosksoft.ru/news/2020/ 12/30/singapurskaya-set-fandomatov-dokazala-svoyu-effektivnost-77296 [in Russian].

21. V Kitae otkryli 20-metrovyj avtomat po prodazhe avtomobilej [20-meter car vending machine was opened in China]. Retrieved from https://rau.ua/ru/news/avtomat-poprodazhe-avtomobiley [in Russian].

22. Symonenko, K. (2019). Prodazhi bez prodavciv: torgovel'ni avtomaty vse chastishe zaminjujut' ljudynu [Sales without sellers: vending machines are increasingly replacing people]. Oficijnyj sajt Asociacii' rytejleriv Ukrai'ny RAU - Official site of the Association of Retailers of Ukraine RAU. Retrieved from https://rau.ua/novyni/ prodazhi-torgovelni-avtomaty [in Ukrainian].

23. Rynok vendyngu - odyn iz najbil'sh dynamichno zrostajuchyh rynkiv [The vending market is one of the fastest growing markets]. Vending-Solution компанії Avangard. Retrieved from http://www.findglocal.com/UA/Vyshneve/112175550419685/VendingSolution [in Ukrainian].

24. Market Information: Data from the official site of European Vending \& Coffee Service Association. Retrieved from https://www.vending-europe.eu/activities/market-information [in English]. 